\title{
ANAESTHETIC MANAGEMENT OF A PATIENT WITH XERODERMA PIGMENTOSA OPERATED FOR BASAL CELL CARCINOMA OF SCALP
}

\author{
Sushil Chand Verma1, Ankesh², Ajit Gupta ${ }^{3}$
}

${ }_{1}$ Senior Resident, Department of Anaesthesiology, RML Hospital, New Delhi.

2Senior Resident, Department of Anaesthesiology, IGIMS, Patna, Bihar.

3Professor and HOD, Department of Anaesthesiology, IGIMS, Patna, Bihar.

HOW TO CITE THIS ARTICLE: Verma SC, Ankesh, Gupta A. Anaesthetic management of a patient with xeroderma pigmentosa operated for basal cell carcinoma of scalp. J. Evolution Med. Dent. Sci. 2018;7(11):1426-1427, DOI: 10.14260/jemds/2018/324

\section{PRESENTATION OF CASE}

Xeroderma pigmentosa[1] is an Autosomal Recessive Genetic disorder of DNA repair, in which the activity to repair damage caused by UV light is deficient. Multiple BCC (Basal Cell Carcinoma) and other skin malignancies frequently occur at a young age in those with Xeroderma pigmentosa. It is a rare disorder characterised by hypersensitivity to sunlight; ocular involvement and progressive neurological complications.

These manifestations ${ }^{[2]}$ are due to UV radiations leading to a defect in repair of DNA by process of Nucleotide Excision Repair (NER). It leads to several challenges in Anaesthetic Management. Here, we are presenting the challenges in Anaesthetic Management in a case of 22 years old male patient suffering from Xeroderma pigmentosa posted for an oncosurgery (BCC of scalp).

\section{DIFFERENTIAL DIAGNOSIS}

Following are differential Diagnosis of Xeroderma Pigmentosa-

- Acanthosis nigricans.

- Acute cutaneous lupus erythematosus.

- Basal cell nevus syndrome.

- Ephelides (Freckles).

\section{CLINICAL DIAGNOSIS}

Here, we are reporting a young adult with diagnosed case of Xeroderma pigmentosa associated with BCC situated over the scalp posted for wide excision and superficial grafting under General Anaesthesia.

A 22 years old young male weighing $50 \mathrm{~kg}$ with Xeroderma pigmentosa had BCC over scalp posted for wide excision and skin grafting.

\section{DISCUSSION OF MANAGEMENT}

During pre-anaesthetic evaluation, he was appearing calm and was able to provide the history from the onset of his skin disorder.

On examination he was average in built, hypopigmented nodules over the face, trunk and extremities.

Systemic examination was normal. Mallampati grading was 3.

His routine investigations (CBC/ECG/CXR/Serum Electrolyte/LFT/KFT) were normal.

'Financial or Other Competing Interest': None.

Submission 02-02-2018, Peer Review 27-02-2018,

Acceptance 05-03-2018, Published 12-03-2018.

Corresponding Author:

Dr. Ankesh,

Sushila Sadan, Behind SBI,

Rajbanshi Nagar, Patna-800023, Bihar.

E-mail: hi2ank@yahoo.com

DOI: $10.14260 /$ jemds $/ 2018 / 324$

\section{(c) (i) $(5)$}

Pre-Operative Vitals were checked and found Stable-

- Under ASA physical status grade 1 with anticipated difficult airway he was accepted after high risk, written and informed consent was obtained.

- Mild sedative tablet Alprazolam $0.2 \mathrm{mg}$ and Ranitidine $150 \mathrm{mg}$ were given the night before surgery. NPO order issued.

- On day of surgery, all difficult airway accessories were kept ready. After taking the patient on operating table baseline blood pressure (NIBP) of 118/78 mmHg, pulse rate of 88 per minute and oxygen saturation of $98 \%$ was noted. ECG, NIBP and SpO2 were used for intraoperative monitoring.

- Peripheral venous access was achieved with an 18-G IV cannula. Patient was pre-medicated with injection Glycopyrrolate $0.04 \mathrm{mg} / \mathrm{kg}$, Fentanyl 2 microgram $/ \mathrm{kg}$ and Midazolam $0.05 \mathrm{mg} / \mathrm{kg}$ IV.

- $\quad$ Patient was pre-oxygenated with $100 \%$ oxygen for 3 minutes and induction was carried out with Propofol $2 \mathrm{mg} / \mathrm{kg}$ followed by Succinylcholine $1 \mathrm{mg} / \mathrm{kg}$. Orotracheal intubation was done with Portex cuffed Endotracheal tube of size $8 \mathrm{~mm}$ (ID).

- Anaesthesia was managed with Dexmedetomidine loading dose of 1 microgram per kg over 10 minutes and then 0.3 microgram per $\mathrm{kg} /$ hour over infusion and nitrous oxide plus oxygen $(50 \%$ each $)$ plus neuromuscular blocker with Atracurium $0.1 \mathrm{mg}$ per $\mathrm{kg}$.

- Analgesia was managed with intravenous Paracetamol $15 \mathrm{mg}$ per kg and Fentanyl 1 microgram per kg.

- Intraoperative haemodynamic parameters remained stable throughout. Surgery lasted for two hours. Patient reversed with Neostigmine $0.05 \mathrm{mg} / \mathrm{kg}$ and Glycopyrrolate $0.01 \mathrm{mg} / \mathrm{kg}$. Xylocard $1 \mathrm{mg} / \mathrm{kg}$ intravenous was given prior to extubation.

Recovery was uneventful with stable vitals. Patient was shifted to PACU for post-operative monitoring.

\section{FINAL DIAGNOSIS}

Xeroderma pigmentosa is an Autosomal Recessive Genetic disorder of DNA repair, in which activity to repair damage caused by UV light is deficient-

- Multiple BCC and other metastatic melanoma and squamous cell carcinomas are most common causes of death in Xeroderma pigmentosa patients.[3]

- This disease involves both types and all races with incidence of 1: 250000 in USA and is roughly 6 times more common in Japanese people than in other groups.

- $\quad$ Patient suffering from Xeroderma pigmentosa presents with many preoperative and intraoperative difficulties for Anaesthesiologist like facial and oropharyngeal changes leading to difficult ventilation and intubation. 
- Prolongation of neuromuscular blocker effect; effect of inhalational agents on NER (nucleotide excision repair).[4,5-7]

- In patients of Xeroderma pigmentosa general anaesthesia using volatile anaesthetic such as halothane causes deranged NER in cell obtained from Xeroderma pigmentosa patient. ${ }^{[8]}$

- We preferred TIVA to volatile anaesthetic uses. Literature studies show that for Xeroderma pigmentosa patient, TIVA is more appropriate than anaesthetic with volatile agents as choice for general anaesthesia. [5]

Muscle relaxant should be used minimally in these patients, as these patients are sensitive to muscle relaxants due to neuronal dysfunctions.

\section{CONCLUSION}

We successfully managed the patient under general anaesthesia using TIVA with minimal dose of muscle relaxants and avoiding volatile agents in the perioperative period.

\section{REFERENCES}

[1] Lehmann AR, McGibbon D, Stefanini M. Xeroderma pigmentosum. Orphanet J Rare Dis 2011;6:70.
[2] Kraemer KH, Lee MM, Scotto J. Xeroderma pigmentosum. Cutaneous, ocular and neurological abnormalities in 830 published cases. Arch Dermatol 1987;123(2):241-50.

[3] Feller L, Wood NH, Motswaledi MH, et al. Xeroderma pigmentosa: a case report and review of the literature. J Prev Med Hyg 2010;51(2):87-91.

[4] Soen M, Kagawa T, Uokawa R, et al. Anaesthetic management of patient with xeroderma pigmentosum. Masui 2006;55(2):215-7.

[5] Masuda Y, Imaizumi H, Okanuma M, et al. Anaesthetic management for patient with xeroderma pigmentosum. Masui (The Japan J of Anesth) 2002;51(2):169-71.

[6] Takahash KT. Anaesthesia for patient with xeroderma pigmentosum. Masui (The Japan J of Anesth) 2007;56(4):439-41.

[7] Oliveria CR, Elias L, Barros AC, et al. Anaesthesia in patient with xeroderma pigmentosum: case report. Rev Bras Anaesthesia 2003;53(1):46-51.

[8] Hasanoglu A, Gucuyener K, Tumer L, et al. Association of xeroderma pigmentosa with thrombosthenia. Turk J Pediatr 1996;38(2):261-4. 